\title{
ガラ紡の力学的な解析と実験
}

信州大学纎維学部 黄 更生・中沢 賢 ·河村 隆

\section{Mechanical Analysis of Garabo and Related Experiments}

\section{Gengsheng Huang, Masaru Nakazawa and Takashi Kawamura}

Faculty of Textile Science and Technology Shinshu University, Ueda, 386 Japan

\begin{abstract}
In Gara-bo spinning, relations among spinning conditions and structural parameters of yarn are very complicated and have not been formulated. when the spinning is in a steady state, some formulae were derived about a relation among the yarn thickness $D$, the twist rate $\lambda$, the established yarn tension $T$ and the fiber density $\rho_{\mathrm{p}}$. Namely,
\end{abstract}

$$
\lambda=\frac{\mathrm{C}_{\mathrm{t} \lambda}}{\sqrt{\mathrm{T}}} \rho_{\mathrm{p}}^{\frac{1}{2 \mathrm{~b}}} ; \quad \mathrm{D}=\mathrm{C}_{\mathrm{td} d} \sqrt{\mathrm{T}} \rho_{\mathrm{p}}^{-\frac{1}{2 \mathrm{~b}}} ; \quad \mathrm{D} \lambda=\mathrm{C}_{\mathrm{d} \lambda} ;
$$

where, $C_{t \lambda}, C_{t d}$ and $C_{d \lambda}$ are coefficients without relation to $T$ and $\rho_{\mathrm{p}}$.

Moreover, based upon the essential principle of Gara-bo, a device was developed for the precise measurement by using electronic technology. Through some experiments done with the device, it is ascertained that $\mathrm{C}_{t \lambda}, \mathrm{C}_{t d}$ and $\mathrm{C}_{\mathrm{d} \lambda}$ can be almost considered as a constant and the theoretical formulae can be used with sufficient suitability. Therefore, when the yarn thickness deviated from the hoped value in spinning process, the compensation quantity of the established tension, which modifies the deviation, can be decided by the formulae.

(Received 10 January, 1997 ; Accepted 19 Septenber, 1997)

\section{1. 緒訔}

ガラ紡機は1877年に日本人卧雲展致により発明された 紡績機械であり，それいは明治初めに日本に輸入された西 洋式の紡績機と原理を全く買にするきわめて独創的な紡 績機である。この紡績機は和紡機とも称され，1890年代 まで西洋式の紡績機と競合して用いられた[1].しかし， 高品質の糸が大量に求められる時代になると，洋式紡績 機に比べ品質・生産性において劣ること，原料の筒への 充填に熟練が必要なことなどの欠点のため，通常の紡績 系の生産には论第に使わなれなくなっていった，それて も，この機械は通常の紡績機では使之ない屑緎維や落綿 などを原料とすることができること，多品種少量生産が 可能であることなど，西洋式紡績機にはない利点を持っ
ているため，現在でも愛知県を中心にわずかであるが 動し，特殊な系の生産に使われている，ガラ紡機を機拣 工学の面からみると，それは現在でも発明当初の機構々 機珹式の制御法をほとんど改良せず用いている。筆者方 は，この機械を制御工学的に解析し現代の制御技術と電 子機器によりメカトロニクス化と改良を行えば，上述の 欠点をカバーできるとともに，従来のがラ紡機よりさら に特殊な形態の系の製造が可能になると考えている。 た，使用原料の面では金属誡維，植物の綿毛や廃萧され たカーボン䋐維など紡績性の悪い材料の紡績あるいは混 紡が可能になると考えている。

ガラ紡に関する学術的な研究は古くより時折り行われ て来た、1940年代の研究 $(2,3)$ は, 綿筒への原料の詰方， 綿筒や巻き取りローラの回転速度の設定など技能的技苻 
的な研究が主である。ガラ紡機を機構の面から洋式紡績 機と比較した研究は比較的新しい，玉川【4〕はがラ紡が 撚り掛けとドラフトを问時に行う点でミュ一ル紡績機に， 緎維束から直接系を形成する点ではオーブンエンド紡績 機に似ていることを指摘している、ガラ紡では紋の太さ は撚り率により敏感に変わるので、撚りと太さの関係の 研究が重要である。 Liddy, 西脇ら〔5,6]は，両者が逆比 例に近い関係になることを寒験により示している。ガラ 紡の機構上の特徽の一つは原料を保持する筒が間欠的な 回転と上下運動をすることである。松本ら $(7,8)$ は原料筒 の上下運動が系の撚り莎と太さに与える影響を測定し， さらにガラ紡系の太さと撚り無の関保を检討し，ガラ紀 機が然り率を系の番手の平方根で除した值が一定になる ように然り率と系の太さが変化する自己平衡性を持つこ とを実験により明らかにしている，松本らの研究ではガ ラ紡を力パート・ヤーンの製造に応用することを目指し ている，筆者ら[9]は力学的制御工学的な観点から紡系 の設定張力(紡系時の系の張力の制御目標值)，筒内の原 料繊維の密度，糸の巻取り速度などのパラメータが系の 太さおよび然り率に及に寸影響を調べそれれらの結果よ リガラ紡にはワットの調速機に匹敵するフィードバック コントロールの機構(自力制御機構)が内在することを明 らかにしている，ガラ紡系の撚り率と太さは紡系張力と 筒内原料の繊維密度により定まるというのが，筆者らの 基本的な考えである，筒内繊維密度は紡系にきわめて重

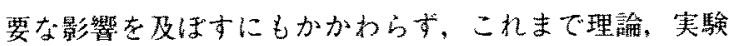
ともに全く検討されていない，また糸の張力が撚り率と 太さに与える影響については一部測定も行われているが， そこに見られる定性的な傾向を説明できる理諭はまだ提 案されていない：この理諭ができないと太さの修正を行 うためのパラメータの変更量を定めることができない．

本論文は紡系の張力、简内の瀻維密度, 形成される系 の太さおよび撚り率の間の関係をできるだけ褯密に測定 し，それら諸量の間に見られる傾向を力学的な関係式で 説明することを試みるものである。筆者らはこれまでの ガラ紡に関する一連の研究の中で，ガラ紡は糸の張力を 一定にするように，然りを操作する紡績法であることを 明らかし，その原理をメカトロニクス化したメカトロニ クス化ガラ紡機(TDS)を考案し，それが制御パラメー夕 の選定により实際にがう紡と同様の紡績が可能であるこ とを示した[10]. メカトロニクス化ガラ紡機は原理は従 来のガラ紀機と同じであるが，徒来のガラ紡機より制御 システムの応答性がよくなり, 糸の張力の制御精度も改 善されているので, 今回の実験ではその装置を用いて測 定を行った。

\section{2. ガラ紡制御の基本動作}

図 1 はガラ紡の機構の模式四である。筒から引き出さ れた繊維により形成された系は，上部の巻き取りローラ に巻き取られる。原料筒はモー夕により回転され筒から 引き出された䋐維汇撚りを与える。系にかかる張力が筒 を持ち上げるに必要な力より大きくなると，筒は上方に 引きけげられる。これによりクラッチ和、 $\mathrm{C}_{2} か ゙$ 外れるの で回転駆動力がなくなり，筒は回転を停止する。このと きでも系は，巻き取りローラにより常に等速で巻き上げ られているので、りフト間に敗まった撚りが次第に少な くなり糸にかかる等便筒荷重(筒の見かけの重さ)により。 系形成域において䋐維間に滑脱が発生し，糸は細くなる。 そしてこの滑脱のため，筒は落下してクラッチが啮み合 い，筒は回転され撚りが再び堌加する。撚りが增加する 上緎維間の滑脱がなくなり筒から系形成域八の引报き緎 維数が増加するので，系は太くなる，やがて，筒は上方 に引上げられ，前と同様の動作を繰り返す。

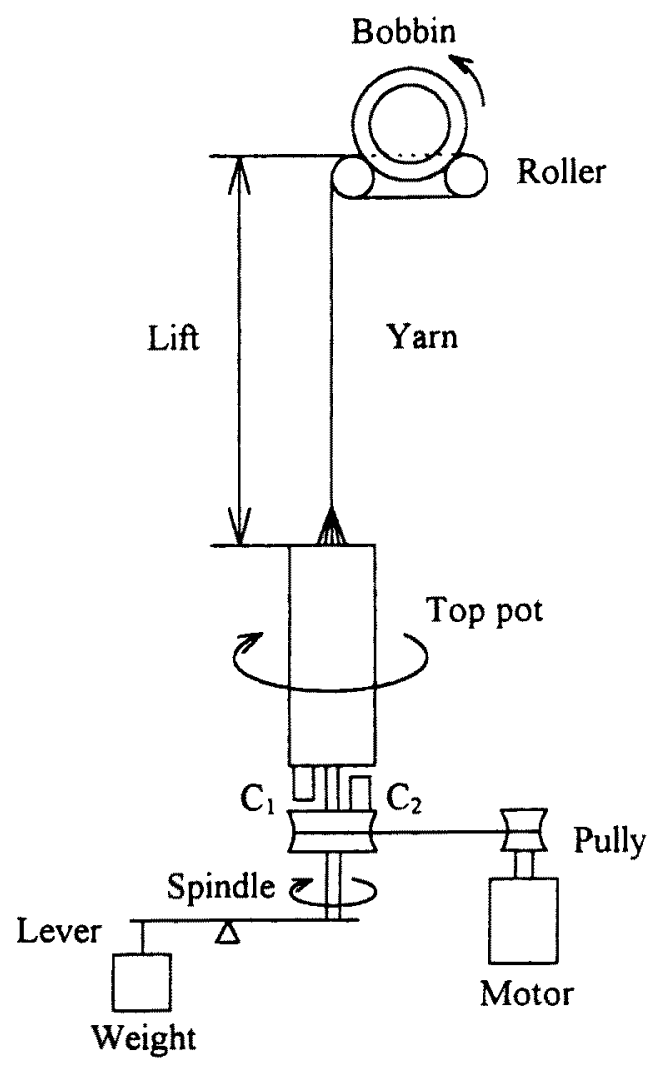

Fig. 1 Sketch of Garabo 


\section{3. 理論式の誘導}

図 2 に筒内原料繊維域，系形成域，糸域の関係を模式 的に示す。ガラ紡では系を紡ぐ時，原料側と系側の間の 遷移域では繊維の先端が系に撚り込まれ㣪端が原料筒か ら引抜きに対する抵抗力を受けでいる。この領域では䋐 維が相互に滑る滑脱状態にあるものと考える、本論文で はこの領域を系形成域と呼ぶ。の領域の纎維の挙動は, 筒内の繊維の密度や織維長分布などが影響してかなり複 雑になる。ここでは筒中の繊維密度は場所によらず常に 一定とする、また本報では紡糸中糸の長さに沿って糸の 太さが変化しない定常状態のみを扱うものとし，系形成 域を図 3 のようにモデル化する.

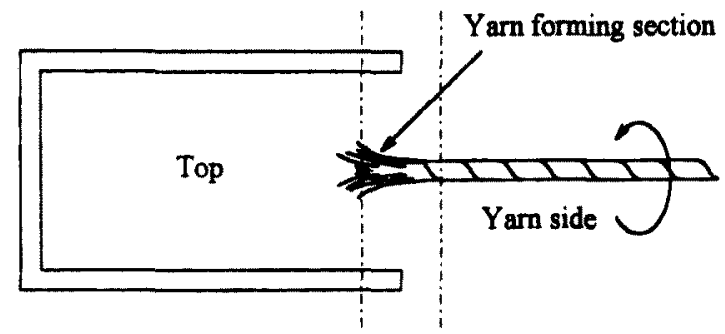

Fig. 2 Schematic diagram of yarn forming section

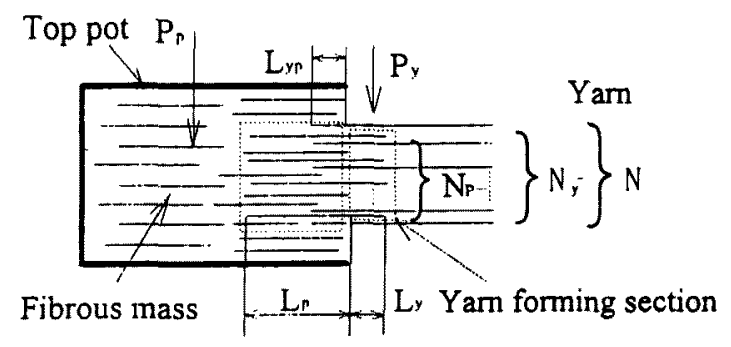

Fig. 3 Dynamic model of yarn forming section

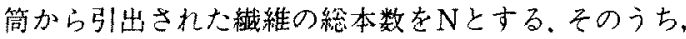
筒の中に下端(図 3 では左端)が入っているが系形成域で 系に対し滑脱しない繊維の本数を $\mathrm{N}_{\mathrm{y}}$ ，それの筒中での平 均長さを $\mathrm{L}_{\mathrm{yp}}$, 筒の中に下端(図 3 では左端)が入っている が系形成域で糸に対して滑脱の可能性がある繊維の本数 を $\mathrm{N}_{\mathrm{p}}$ ，それの筒中での平均與さを $\mathrm{L}_{\mathrm{p}}$ ，亲形成域での平均 長さをL $\mathrm{L}_{y}$ をる。繊維の長さをLとすると

$$
\mathrm{L}=\mathrm{L}_{\mathrm{y}}+\mathrm{L}_{\mathrm{p}}
$$

である、ここでは単純化のため, Lはすべての単繊維で同 じであるとする。また，系の巻取り速度は一定であると する、Nに占める $N_{\mathrm{p}}, \mathrm{N}_{\mathrm{y}}$ の割合を $\beta_{\mathrm{p}}, \beta_{\mathrm{y}}$ とすると。

$\beta_{\mathrm{p}}=\mathrm{N}_{\mathrm{p}} / \mathrm{N}, \quad \beta_{\mathrm{y}}=\mathrm{N}_{\mathrm{y}} / \mathrm{N}$
このとき,

$$
\mathrm{N}=\mathrm{N}_{\mathrm{p}}+\mathrm{N}_{y}
$$

であるから、

$$
\beta_{\mathrm{p}}+\beta_{\mathrm{y}}=1
$$

である，定常状態ではは定数と仮定する.

\section{1 筒側馀維の拘束力}

まず,筒から采形成域に筒側の拘束力に抗してN本の維 維を引出すに必要な力を考える.Cox[11], Hannah[12], 我妻[13]の提案する理論を用いると, $\mathrm{L}_{\mathrm{yp}}$ の長さが简内に ある $\mathrm{N}_{\mathrm{y}}$ 本の戰維を引き出すに要する力 $\mathrm{f}_{\mathrm{p}}$ はいずれも次式 により表される。

$$
f_{p}=g\left(N_{y} \frac{2 d \mu L_{y p}}{l-\varepsilon_{p}} P_{D}\right)
$$

ここで, $\mathrm{P}_{\mathrm{p}}$ は原料筒中の㵶維に働く横方向圧力, dは䄉 維の直径, $\mu$ は纎維間の摩擦係数である. $\varepsilon_{\mathrm{p}}$ は緎維束の空

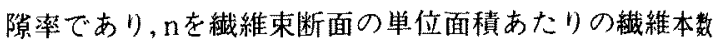
とすると， $\varepsilon_{\mathrm{p}}=1-\pi \mathrm{d}^{2} \mathrm{n} / 4$ である，gは定数係数で，Cox らの理論を用いると $\mathrm{g}=1$, 繊維長が一定としてHannahの 理論を用いると， $g=1 / 3$ 我妻の理論では $\mathrm{g}=1 / 2$ となる。 Coxの理論は横方向からの圧力を受けている平行䋐維の束 加ら単嶻維を引抜く際の摩擦抵抗力を求めたものであり, Hannahと我妻の理論は繊維束を 2 点で把持して引くとき の滑脱の摩擦抵抗力を扱ったものであり，引く繊維とこ れを拘束する繊維の本数が同程度である。枺ら[14]活 械維束から数本の繊維を引抜く時の摩擦力を測定し，そ れが引抜き繊維本数にほほ比例することを示している. 以上いずれの理論および実騒も引抜きの抵抗力は引き技 く纎維本数に比例することを示している。本研究の場合

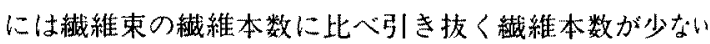
ので，便宜上 $\mathrm{g}=1$ を採用することにする。したがって

$$
\mathrm{f}_{\mathrm{p}}=\mathrm{N}_{\mathrm{y}} \frac{2 \mathrm{~d} \mu \mathrm{L}_{\mathrm{yp}}}{1-\varepsilon_{\mathrm{p}}} \mathrm{P}_{\mathrm{p}}
$$

同様に $\mathrm{L}_{\mathrm{p}}$ の長さが简内にある $\mathrm{N}_{\mathrm{p}}$ 本の繊維を引き出すに必 要な力的は论のようになる

$$
f_{p y}=N_{p} \frac{2 d \mu L_{p}}{1-\varepsilon_{p}} P_{p}
$$

筒からN本の繊維を引き出すに必要な力すなわち糸の張 力は $\mathrm{F}=\mathrm{f}_{\mathrm{p}}+\mathrm{f}_{\mathrm{py}}$ であるから，式(1)（4)より

$$
\mathrm{F}=\mathrm{N}-\frac{2 \mathrm{~d} \mu \mathrm{L}_{\mathrm{s}}}{1-\varepsilon_{\mathrm{p}}} \mathrm{P}_{\mathrm{p}}
$$

ただし，Lsは筒側の拘束をを受ける繊維の拘束の等伍 舆さであり，

$$
\mathrm{L}_{\mathrm{s}}=\beta_{\mathrm{p}} \mathrm{L}_{\mathrm{p}}+\beta_{\mathrm{y}} \mathrm{L}_{\mathrm{yp}}
$$

\section{2 釆側の撚りによる拘束力}

糸形成域で滑りうる $\mathrm{N}_{\mathrm{p}}$ 本の纎維が，糸側の撚りから受 ける拘束力 $\mathrm{f}_{\mathrm{yp}}$ は, Hannahの理論により。 


$$
f_{y p}=N_{p} \frac{2 d \mu L_{y}}{3\left(1-\varepsilon_{y}\right)} P_{y}
$$

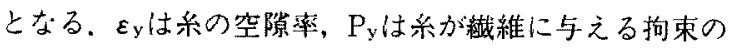
平均圧力である，系，あるいは撚りのかかった緎維束に おいては撚りに起因して横方向圧力が生じるがSmith[15] の考え方を採用すると，その平均圧力はP

$$
\mathrm{P}_{\mathrm{y}}=2 \pi \mathrm{F} \lambda^{2}
$$

となる。ここで入は糸の撚り率である.定常状態では紡系 張力は制御の目標值T (設定張力)に一致していると考えて よいので,

$$
\mathrm{F}=\mathrm{T}
$$

とすると、式 $(6)$ - (8) より

$$
f_{y p}=N_{p} \frac{4 \pi d \mu L_{y}}{3\left(1-\varepsilon_{y}\right)} T \lambda^{2}
$$

\section{3 米形成域でのカの鈞合い}

系形成域で滑りうるNo本の繊維が滑らず引出される条 件はf $\mathrm{yp}_{\mathrm{p}} \geq \mathrm{f}_{\mathrm{py}}$ である。撚りが増加して纎維が引出されるよ うになるのは，式(4)，(9)より

$$
\frac{2 \pi L_{y}}{3\left(1-\varepsilon_{y}\right)} \mathrm{T} \lambda^{2}=\frac{L_{p}}{1-\varepsilon_{p}}
$$

となるときである，上式中の $\varepsilon_{\mathrm{p}} 、 \varepsilon_{\mathrm{y}}$ はそれぞれ $\mathrm{P}_{\mathrm{p}}$ および

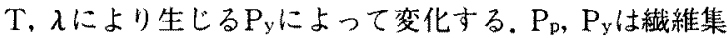
合体の密度の関数とみることもできる。一般に緎維集合 体の充填率 $(1$-纎維集合体の空隙率) と繊維集合体の密度 との閒には比例の関保があり，筒内の原料と形成される 系の密度 $\rho_{\mathrm{p}}, \rho_{\mathrm{y}}$ は次式で与之られる。

$$
\begin{aligned}
& 1-\varepsilon_{\mathrm{p}}=\frac{\rho_{\mathrm{p}}}{\rho_{\mathrm{f}}} \\
& 1-\varepsilon_{y}=\frac{\rho_{y}}{\rho_{\mathrm{f}}}
\end{aligned}
$$

ここでのは単織維の密度である。

Sebestyenら〔16]は圧力Pと密度のの関係として,次の実 験式を提案している.

$$
\rho=\mathrm{aP}^{\mathrm{b}}
$$

ここで、，bは繊維の物性值，形状および䋐維長分布な どで定まる定数である。彼らの研究は羊毛に対して行わ れたものであるが，ほかの㵶維にもほぼ適用できると考 えられる。式(11)～(13)を用いて式(10)上り入を $\rho_{\mathrm{p}}, T$ の 関数として求好ると。

$$
\begin{aligned}
\lambda & =\frac{C_{\mathrm{t} \lambda}}{\sqrt{\mathrm{T}}} \rho_{\mathrm{p}}^{\frac{1}{2 b}} \\
\text { ただし, } & \\
\mathrm{C}_{\mathrm{t} \lambda} & =\sqrt{\frac{1}{2 \pi}} \mathrm{a}^{-\frac{1}{2 b}}\left(\frac{3 \mathrm{~L}_{\mathrm{p}}}{\mathrm{L}_{\mathrm{y}}}\right)^{\frac{1}{2(1-\mathrm{b})}}
\end{aligned}
$$

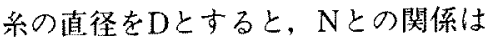

$$
\frac{\mathrm{D}^{2} \pi}{4}=\frac{\mathrm{d}^{2} \pi}{4\left(1-\varepsilon_{\mathrm{y}}\right)} \mathrm{N}
$$

であるがら，式(5)，(7)，(11)（14）を上式に用いると，

$$
\mathrm{D}=\mathrm{C}_{\mathrm{td}} \sqrt{\mathrm{T}} \rho_{\mathrm{p}}^{-\frac{1}{2 \mathrm{~b}}}
$$

ただし，

$$
\mathrm{C}_{\mathrm{td}}=\frac{\mathrm{dC}_{\mathrm{t} \lambda}{ }^{-\mathrm{b}}}{\sqrt{(2 \pi)^{\mathrm{b}} 2 \mathrm{~d}_{\mu} \mathrm{L}_{\mathrm{s}} \mathrm{a}^{\frac{\mathrm{b}-1}{b}}}}
$$

式(14),(16)より，Dと入の関係は次のようになる。

$$
\mathrm{D} \lambda=\mathrm{C}_{\mathrm{d} \lambda}
$$

ただし，

$$
\mathrm{C}_{\mathrm{d} \lambda}=\mathrm{C}_{\mathrm{td}} \mathrm{C}_{\mathrm{t \lambda}}
$$

式(17)はТと $\rho_{\mathrm{p}}$ を陽に含まない。

\section{4. 実験装置および方法}

\section{1 綿樴維集合体の圧縮特性の測定}

筒内原料について式(13)の定数a，bを定めるために次 の実騃を行った.図 4 のように原料の綿践維を長さ $68 \mathrm{~mm}$, 幅 $68 \mathrm{~mm}$, 高さ67mmの内壁を研磨した立方体の容器に入 れ図4のような精密万能試験機 (Computer control system Shimadzu Autograph AG-20 KND)により圧板に圧縮力 を加え，その変形量を調へた。，測定は次の三種類の綿緎 維集合体の状態に対して行った。

(A) 引きそろえた平行綿繊維をそのまま測定容器に 入れた状態。

\section{Pressure sensor}
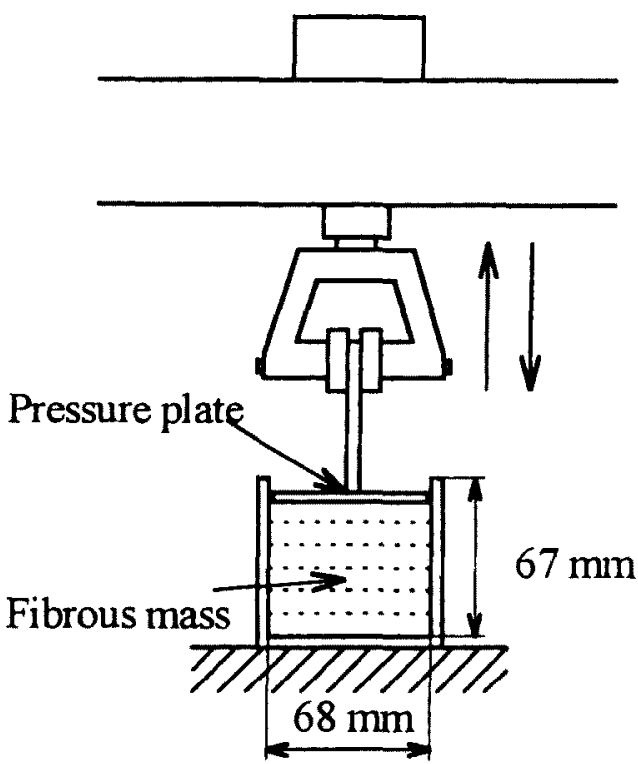

Fig. 4 Sketch of compression test apparatus 


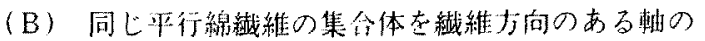
まわりに月简状に管いな状態。

（C）緎維の方向をランダムにした状熱。

压板の降下上果速度は $10 \mathrm{~mm} / \mathrm{min}$ とた。綿密度の初

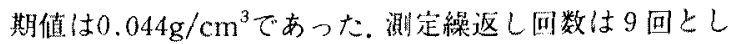
た.

\subsection{TDS装觜のシステム楆成}

网1のガラ紡機をその原玨を生かし，現代の電子機器 と制御技政でメカトロニクス化したガう搂機(T.D.S)の構 成を图 5 に示す、筒の回転軸はサーボモー夕に直結され， 筒の回転はこのサーボモー夕により制御する。系の張力 F䶮張力センサにより测定し、それをパソコンに取り込み，

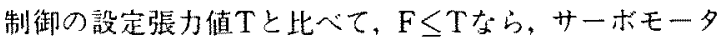
をあら的し設定した回転速度て回転させ，F>Tなら， サ一ボモ一夕の回䎐を停止する。つまり，往来のが紡 機と同しように張力により筒の回転に対してオンオフ制 御を行う.ガラ紡では系張力が大きくなると，筒は上力に 引上げられるが、この上下運動はクラッチをオフにす るなめに必要なたけで原理上は不要なので, TDSではこ れを行力安い構造にしている。筒の回転速度の检出には

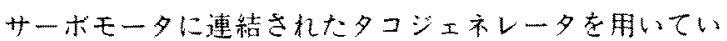

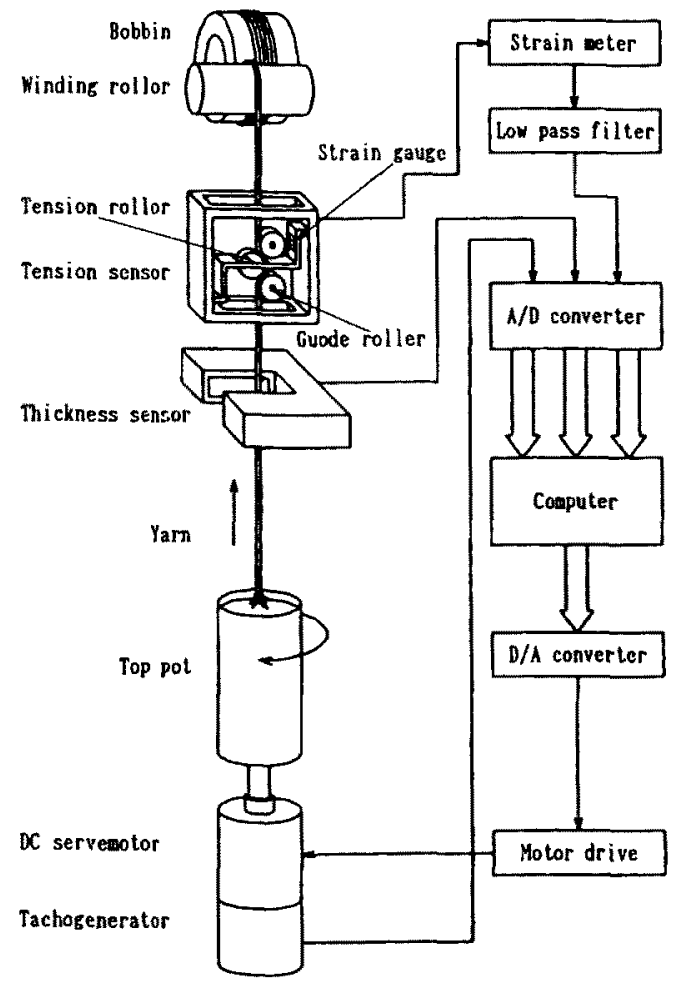

Fig. 5 Schematic diagram of experimental apparatus
る。卷さ取りローラはサーボモータにより駆動され，巻 取り速度は減速機の減速比变之ることにより加減て る。なお，系の太さはレーザ太さきンサ(LS-3000 Laser scan diameter)により検出している.

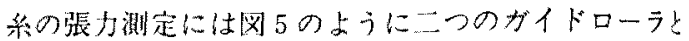
テンション測定ローラからなる装置を作成して用いた。 テンションローラの軸はZ字状の板ばねに上り支持されて おり，ローラにかかる力板ば权の固定点近くに貼㑬 なストレインゲージにより検出し，これにより系の张力 を算出している.ここては数Nから16N程度までの比較的 広い範囲の力在测定する必要上，テンションローラの移 動長さが大きくなっも，草の軌跡が直線からあまり外 れない上うにするため，板代社を片持ちはり状にせず， Wattの疑似直楾運動機構に類似のクランク状機搆にした。 系の撚り率の测定は，普诵はでき上がった系をボビン から取り外した後，系の撚りを医して測定する方法加用 いられるが、ここではオンライン計測を行う関係上，サ 一ボモータの回転速度の時閒に対する過途的な変化を考 虑した次式により撚り率を計算した[17]。

$$
\lambda=\left(\lambda_{0}-\mathrm{n}_{\mathrm{p}} / \mathrm{v}\right) \exp \left\{\left(-\mathrm{v} / \mathrm{L}_{0}\right) \mathrm{t}\right\}+\mathrm{n}_{\mathrm{p}} / \mathrm{v}
$$

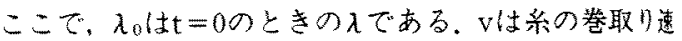
度， $\mathrm{n}_{\mathrm{p}}$ は筒の回転速度，L。はリフトである。

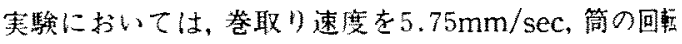
速度8.33turns/secを、リフトを700mmに設定した。ま 設定張力の影響を調べる寒験においては简に詰める原料 綿繊維の密度は $0.138 \mathrm{~g} / \mathrm{cm}^{3}$ とし、設定張力を0.1Nから0.55 Nまで0.05Nずつ変化させ、それぞれに対する張力, 太主 と然り率を測定してハタコンに取り込んた。简内の原料

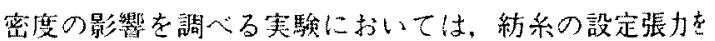
$0.2 \mathrm{~N}$ に固定して，筒内原料密度老 $0.077 \mathrm{~g} / \mathrm{cm}^{3}$ 名 50.163

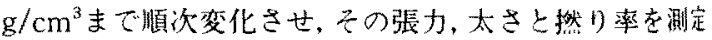
しな，なお，実娩は温度 $22^{\circ} \mathrm{C}$, 湿度 $69 \%$ の恒温恒湿室内 に挍いて行った。

\section{5. 実験結果と考察}

\section{1 原料織維藮合体の圧縮特性}

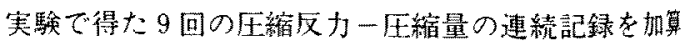
平均し，压力一密度の関係に掺算し雨对数座標平面に画 くと，园6のようになる。图中のA，B，Cはそれぞれ4、1 節の (A)，(B)，(C)の緎維集合体の状態に対寸る值である ことを示す、いずれの場含も而对数座標平湎でははとんと 淔線になる。これりbの值を求めると表1のようになる。 原料の種類が同しでも瀻維集合状態により係数bの值杜黑 なることが加る。 


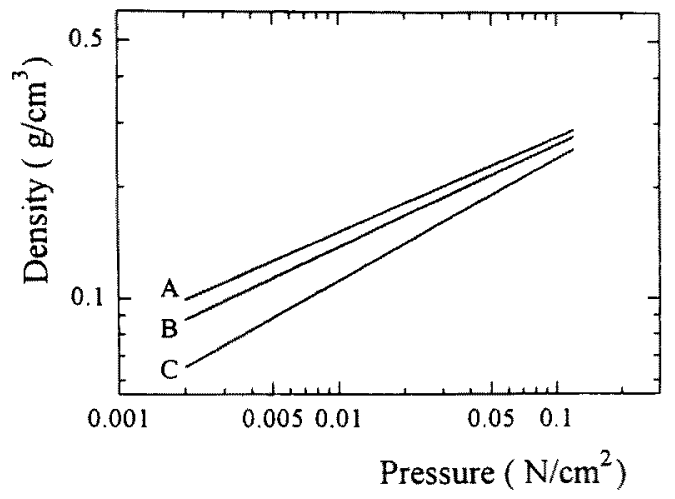

Fig. 6 Relation between pressure and density

Table 1 Measured values of $b$

\begin{tabular}{lccc}
\hline Kind of fibrous mass & A & B & C \\
\hline Measured value of $b$ & 0.26 & 0.28 & 0.34 \\
\hline
\end{tabular}

\subsection{TDSの紡米結果と考察}

\subsection{1 米の制御張力の影響}

図7－9に平均撚り率と太さに対する平均系張力の影響 を示す。箕，横軸ともに対数目盛で表示している。印 は測定值を，それに接続する座標方向の直線はその測定 值の上下限を示寸，実験值に対し，最小二乗誤差法によ り求めた近似直線を実線で示す。また，式(14)，(16)，(17) による理論勾配直線を破線で示す。

\subsubsection{1 平均燃り事に対する影響}

図 7 は平均撚り率に対する平均系張力の影響を示す。 系の平均張力の增加に従って糸の平均撚り率は雨対数目 盛の平面でほほ直線的に下がっており，その勾配の大焉 きを求めると $\mathrm{K}=0.57$ となり，理論式(14)のTのべき数 0.5 にかなり近い值になる。このことはC、ははほほTの関数で ないと見てよいことを意味している，実験の近似直楾の 勾配は理論のそれより小さくなるが，その原因は張力が

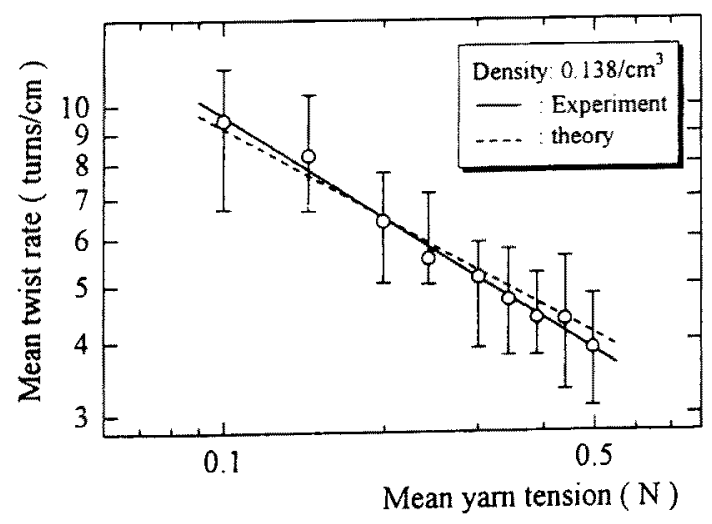

Fig. 7 Relation between tension and twist rate
大きくなると糸形成域に引き出される䋐維本数が多くな るので, 纎維引き出し点近傍の綿筒表面の瀻維密度が小 さくなるためと若えられる。

\subsubsection{2 米の平均太さに対する影響}

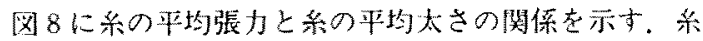
の平均張力の增加に砳って糸の平均太さは大きくなる。 実験值の近似直線の勾配の大きさは $\mathrm{K}=0.55$ となり,前節

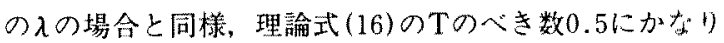
近い值となりC $\mathrm{tad}_{\mathrm{d}}$ 大略Tの関数でないと見てよいことが わかる、図7,8において理論と実験の勾配の大きさがとも に0.5に近いことは理論における $れ \propto 1 / \sqrt{T} ， \mathrm{D} \propto \sqrt{\mathrm{T} か ゙ 冖 ~}$ 当であることを意味し，それは撚りによる拘束力の报い に関してSmithの理論を採用することが妥当であることを 意味している.

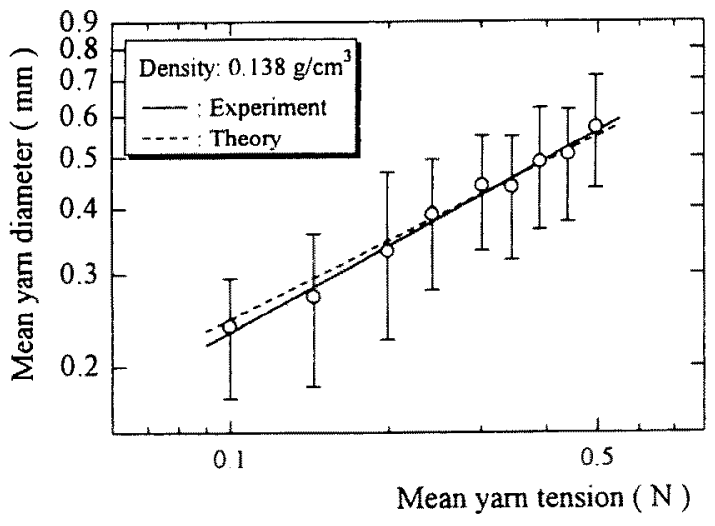

Fig. 8 Relation between tension and yarn diameter

\subsubsection{3禾の平均太さと平均然り率の関係}

糸の平均太さと糸の平均撚り津の関保を求めると, 図

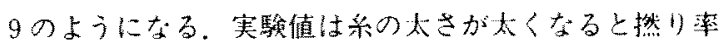
が直線的に下ることを示している，その近倾直線の勾配

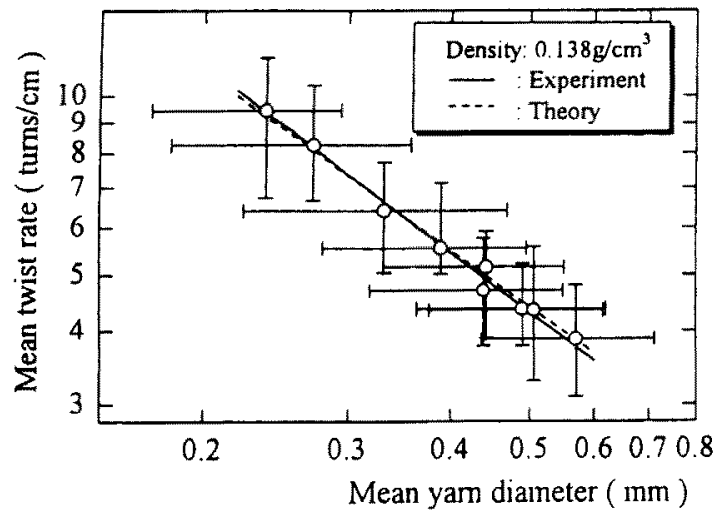

Fig. 9 Relation between yarn diameter and twist rate 
はとなり、式(17)において $\mathrm{d}$ をTに無関係な定数とみな したときの勾配一0.1にほとんど一致する。

\section{2 .2 筒内原料密度の影響}

図10１2に平均撚り率と太さに対する筒内原料密度の影 暃を示寸。縦，横軸ともに対数目盛で表示している。 印は測定值を，それに接続する縦座栖方向の直線はその 測定值の上下限を示す。图7－9と同様，実線は実験值の 最小二乗誤差の近似直線を、破線は理論勾配直線を示す。 A，B，Cは4.1節の (A)，(B)，(C)に対する測定值を用い た式(14)，(16)，(17)による理論勾配直線を示す。

\subsubsection{1 平均撚り率への影響}

図10に各筒内原料密度に対する平均撚り率の变化を示 す。筒内原料密度に対する平均撚り率の実騃值の変化は ほほ直線状になる。C $\mathrm{C} \lambda$ を仮りに $\rho_{\mathrm{p}}$ に無関倸な定数として 実験の近似直線の勾配より逆算して保数bの值を求めると, $\mathrm{b}=0.37$ となる.これに対し 4.1 節の $(\mathrm{A}),(\mathrm{B}),(\mathrm{C})$ の状態 それぞれに対するbの測定值は表1の通りで案駼值に近い。 これよりC齐はほほ $\rho_{\mathrm{p}}$ と無関保な定数と見なしてよいこと がわかる（C)の測定値が実騟値に最も近くなっている.

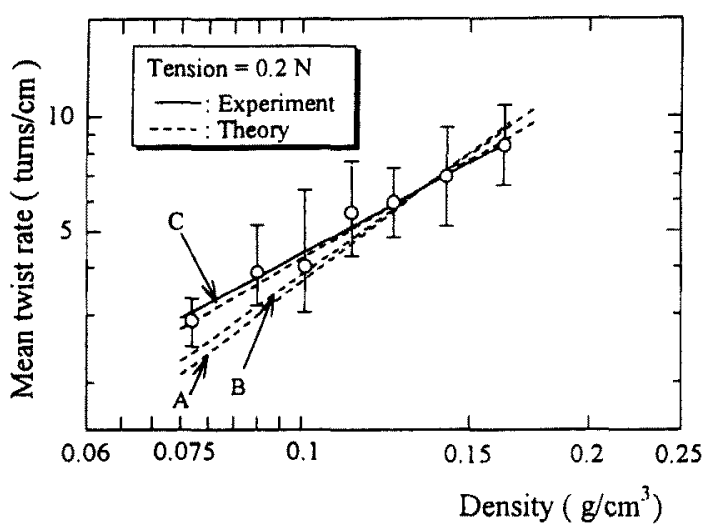

Fig.10 Relation between density and twist rate

\subsubsection{2 平均太さへの影響}

図11に筒内原料密度と系の平均太さの関保を示す，原 料密度の增加に従って系の平均太さは下がるという傾向 を示している，前節と同様， $C_{t d}$ を $\rho_{\mathrm{p}}$ に無関係な定数と仮 定して，寒験の近似直線よりbを逆算して求めると， $\mathrm{b}=$ 0.35 となり，表 1 の值にかなり近く， $\mathrm{C}_{\mathrm{ta}}$ は $\rho_{\mathrm{p}}$ に無関係な 定数とみなせることがわかる，直感では円筒状に繊維集 合体を巻いた状態 (B)が実際の筒内の㵶維の配列状態に 番近いので，そのときのbを用いた理論線が $(\mathrm{A})$ ，(C)によ る理論線より実験值に近いと尒想したが，現実はランダ 厶状(C)に対して得たbを用いたCの理諭勾配直線が実験值 に一番近くなっている。しかし，その理由ははっきし

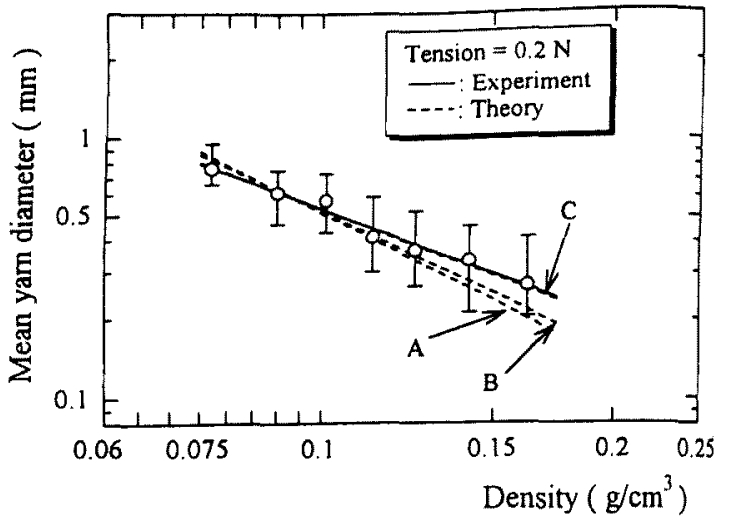

Fig.11 Relation between density and yarn diameter ない。

\subsubsection{3 平均太さと然り率の関係}

図12は平均太さと平均撚り率の関保を示す，実駼做の 近似直線の勾配は一0.96であり，理論式(17) と比べると $\mathrm{C}_{\mathrm{d}}$ をほぼ $\rho_{\mathrm{p}}$ に無関保な定数とみなしたときの理論勾配一 1.0にほほ一致する、罒12を図10，11と比べると，理猃值 と実験颠のずれがかなり小さいことがかかる。これは式 (17)にbの影響がでやすい 考えられる。

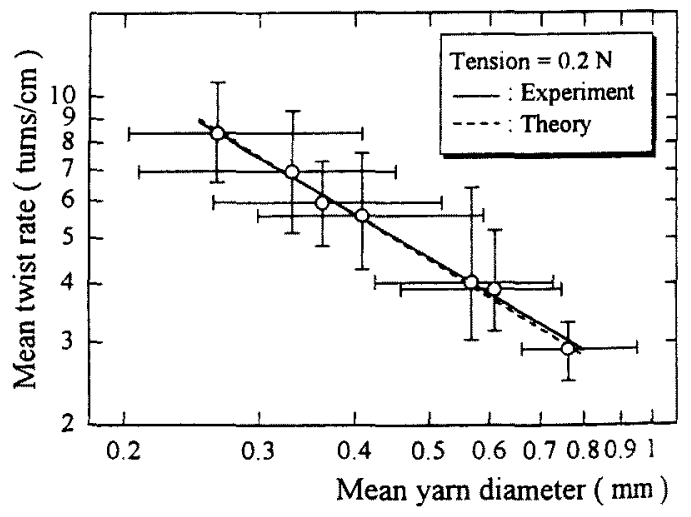

Fig.12 Relation between yarn diameter and twist rate

\subsection{3 係数 $\mathrm{C}_{\mathrm{t} \lambda}, \mathrm{C}_{\mathrm{td}}, \mathrm{C}_{\mathrm{d} \lambda}$ の定数性}

5.2.1節，5.2.2節において扱った実験值より得られた $\mathrm{K}, \mathrm{b}$ の平均值を求めると, $\mathrm{K}=0.56, \mathrm{~b}=0.36$ となる。 の值を用いて今回の実験における $\mathrm{C}_{\mathrm{t} \lambda}, \mathrm{C}_{\mathrm{td}}$ 求めると表? になる，表より平均張力，筒内原料密度のいずれの值を 変化させた場合にも得られる係数值はお互にかなり近り ことがわかる。すなわち，係数 $\mathrm{C}_{\mathrm{t}}, \mathrm{C}_{\mathrm{td}}, \mathrm{C}_{\mathrm{d}}$ はおよその

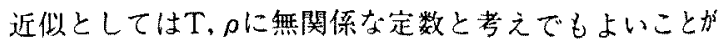
わかる.これより，定常状態のとき，解析モデルにおけ 
Table 2 Measured values of $\mathrm{C}_{t \lambda}, \mathrm{C}_{\mathrm{td}}, \mathrm{C}_{\mathrm{d} \lambda}$

\begin{tabular}{|c|c|c|c|}
\hline Test condition & $C_{t \lambda}$ & $\mathrm{C}_{\mathrm{td}}$ & $\mathrm{C}_{\mathrm{d} \lambda}$ \\
\hline $\begin{array}{l}T=\text { Variable } \\
\rho=\text { Constant }\end{array}$ & 41.26 & 0.052 & 2.10 \\
\hline $\begin{array}{l}\mathrm{T}=\text { Variable } \\
\rho=\text { Constant }\end{array}$ & 42.96 & 0.054 & 2.33 \\
\hline
\end{tabular}

る $\mathrm{L}_{\mathrm{s}} ， \mathrm{~L}_{\mathrm{p}}$ は定数と仮定してもよいことになる。また，糸 の太さと采の撚り率の積は糸の張力と原料繊維密度に無 関保であることが明らかになった。

\section{6. 結 言}

本論文では，まずガラ紡においては糸と原料筒間に緎 維の滑脱が可能な遷移領域が存在すると仮定してモデル 化を行い，定常状態の場合につき，系の太さおよび系の 撚り率を系の制御張力と筒内原料密度上り定める理論式 を導いた，それによると，糸の太さは系の制御張力の平 方根および筒内原料密度の $(-1 / 2 b)$ 乗の積に比例し, 撚 り率はそれに逆比例する，次にメカトロニクス化ガラ紡 機を用いて，筒内原料密度と系の制御張力の影響を調べ る実験を行い, 糸の平均張力, 筒内原料密度, 系の平均 太さおよび平均撚り率の間の関係を調べた。それより， 定常状態においては撚り率，太さ，太さと撚り率の樍を 与之る式の係数 $\mathrm{C}_{\mathrm{t} \lambda}, \mathrm{C}_{\mathrm{td}}, \mathrm{C}_{\mathrm{d} d}$ は近似的に糸張力と筒内の 原料密度によらない定数と考之てよいことがわかり，理 論の妥当性が立証された。これらの関係式を用いればが ラ紡の紡系中に系の太さが希望する值からずれたときに，
これを修正する設定張力の補正量を知ることが可能にな る。

\section{文献}

1. 北野 進、「臥雲辰致とガラ紡機」アアグネ技術セン 夕-(1994).

2．矢橋彦四郎，繊維技術，34，963-1055(1943)。

3. 矢橋彦四郎，械維技術，35，98-102(1944)．

4.玉川寛治，技術之文明，3，1-20(1986)。

5. D. T. Liddy and E. F. Denby, J. Text. Inst. 51, T1109T1119(1960).

6. 西脇慈圆ほか，㵶学誌，33，138-140(1950).

7. 松本陽一ら, 襶機誌, 46, T215-T225(1993).

8. 松本陽一ら, 繊機誌, 47, T83-T88(1994).

9. 中沢 賢ら, 繊機誌, 47, T181-189(1994)。

10. M. Nakazawa et al., Proceedings of The 2nd International Silk Conference, China, P.366.-373 (1993).

11. D. R. Cox, J. Text. Inst., 43, T87-T90 (1952).

12. M. Hannah, J. Text. Inst., 41, 57 (1950).

13. 我妻直夫, 「基礎緎維工学[ I ] , 日本繊維機械学会, P.293-P.297 (1965).

14。木下万，繊学誌，16，935-939(1960).

15. P. A. Smith, J. Text. Inst., 53, T511-T528(1962).

16. E. Sebestyen, T. Shickie, J. Text. Inst, 62, 545-560 (1971).

17. 渡辺 茂, 機械の研究, 1, 441-446(1951)。 